\title{
Frameworks for Formation and Stability of Kurgan Regional Arboretum Phytocenosis
}

\section{N P Nesgovorova', V G Saveliev", G V Ivantsova', A A Purtova', and M G Ufimtseva ${ }^{2}$}

${ }^{1}$ Department of Geography, Fundamental Ecology and Nature Management, Kurgan State University, Kurgan, Russia

${ }^{2}$ Department of Ecology and Environmental Management, State Agrarian University, Northern Trans-Urals, Tyumen, Russia

\section{Abstract}

The article is devoted to solving the problem of biodiversity conservation in the framework of increasing sustainability of natural plant communities in arboretum being an artificial protected area. Research and application have accumulated significant knowledge on various aspects of the above problem, specifically, preserving biodiversity including vegetation, monitoring biodiversity and preserving phytocenosis, plant interaction in phytocenosis, causes of disturbed biodiversity and reducing

Corresponding Author:

N P Nesgovorova

natali_348@mail.ru

Received: 25 October 2019

Accepted: 15 November 2019

Published: 25 November 2019

Publishing services provided by Knowledge E

(c) N P Nesgovorova et al. This article is distributed under the terms of the Creative Commons Attribution License, which permits unrestricted use and redistribution provided that the original author and source are credited.

Selection and Peer-review under the responsibility of the AgroSMART 2019 Conference Committee.

\section{G OPEN ACCESS} phytocenosis stability, etc. The research objective is to theorize the frameworks for phytocenosis formation, identify the factors influencing phytocenosis stability, conduct observations and experimental research on the factors affecting the formation and stability of the Kurgan regional arboretum phytocenosis. The models of the way different factors influence the resistance mechanisms of the Kurgan regional arboretum phytocenosis are built as a result of studying research materials and differ from the theoretical model in the fact that the proven distinctions were found in the ratio of limiting and background factors reflecting their regional character.

Keywords: phytocenosis, phytocenosis stability mechanisms, limiting factors

\section{Introduction}

Relevance of this work lies in the fact that any natural, natural-anthropogenic communities include a phytocenosis (plant) as a component creating its structure.

Arboretums, arboretum parks, arboretum gardens are protected areas which are created artificially. In the majority of cases, newly created arboretums seldom include natural phytocenosis. Most often they are created artificially by modeling communities using plants similar to life support factors. The Kurgan regional arboretum is a newly created community as well. Its distinguishing characteristic is the areas with preserved natural communities being community of the pine forest (Scotch pine -- Pínus sylvéstris 
L.), a small-leaved forest with Birch Krylov (Betula krylovii G. Kryl) and Aspen (Topol trembling -- Pópulus trémula L.) as forest-forming species, mixed forest communities on the territory allotted to it.

The problem of preserving biodiversity including vegetation is quite thoroughly considered in the works of S. Hagvar (1998) [1], P. Laihonen, M. Ronka, H. Tolvanen, R. Kalliola (2003) [2], H. Hillebrand, B. Matthiessen (2009) [3] and other scientists.

Control over phytocenosis biodiversity and conservation was considered in the works of K.A. Kurkin (1998) [4], A.H.Prieur-Richard, S. Lavorel, Ya. Linhart, A.Dos Santos (2002) [5], Ja. Ruijven, G.B. De Deyn, F. Berendse (2003) [6], J. Landsberg, G. Crowley (2004) [7], J.D. Bever, T.G. Platt, E.R. Morton (2012) [8], S. Hu, Y. Li, W. Wang, J. Jiao, M. Kou, Q. Yin, H. Xu (2017) [9], S. Mukhopadhyay, V. Rana, S.K. Maiti, A. Kumar (2017) [10].

Interaction of plants in phytocenosis and the efficiency of creating long-term selfrenewing phytocenosis are considered in the following works: K.A. Kurkin (1999) [11], V.G. Onipchenko, O.S. Vertelina, M.I. Makarov (1998) [12], P.R. Makarevich (2009) [13], K.N. Privalova, N.V. Zhesmer, M.V. Blagorazumova (2010) [14], M.G. Romanovsky, T.S. Zavidovskaya (2010) [15].

The importance of studying the problem of preserving natural complexes and introducing new plant species into the native phytocenosis has been studied by V.S. Ipatov (2013) [16], K.P. Danilov, N.A. Kirillov, A.I. Volkov (2015) [17], O.G. Kalmykov, P.V. Velmovsky, A.G. Bakiyev, R.A. Gorelov (2017) [18].

The definition of phytocenoses stability criteria and their modeling is covered in the works of T.V. Dymova (2009) [19], T.A. Trifonova, L.A. Shirkina, N.V. Mishchenko (2012) [20], O.A. Sorokina, A.N. Rybakova (2012) [21], E.O. Korolkova, A.V. Shkurko (2016) [22].

The causes of biodiversity disturbance and phytocenosis stability reduction are discussed in the works of L.O. Karpachevskii (1996) [23], G.V. Kuznetsov, L.V. Zotova (2001) [24], A.M. Mustafina, A.G. Tyuryukov (2012) [25].

The negative influence of anthropogenic factors, including the recreational impact on the phytocenosis, and, specifically, artificial one was revealed in the works of O.N. Zubareva, L.N. Skripal'shchikova, V.D. Perevoznikova (1999) [26], K.A. Kosnazarova, B.A. Rakhmanov, K.Zh. Eshzhanova, K.K. Kosnazarova, L.K. Romanova, T.ZH. Orazbayev (2016) [27], T.V. Kritskaya, L.V. Levchuk (2016) [28], I.V. Tyrchenkov (2017) [29].

Identifying and substantiating the mechanisms of phytocenosis formation will help identify the missing species in the already existing phytocenosis of the Kurgan arboretum in order to model the ideal plant community. Determining the factors affecting the stability of the phytocenosis will help determine the factors of preserving the structure 
and functional properties of the existing plant communities under the influence of environmental factors.

The main contradiction is that research and practice justify phytocenosis formation but the existing phytocenotic communities of the Kurgan arboretum are poor in species composition and the factors contributing to the preservation of plant communities and mechanisms affecting their formation in the Kurgan regional arboretum have never been the subject research.

The problem of the research is as follows: what factors influence the formation and stability of the Kurgan regional arboretum phytocenosis?

The objective of the research is to theoretize phytocenosis formation, identify factors that influence phytocenosis stability, conduct observations and experimental research on the factors affecting the formation and stability of the Kurgan regional arboretum phytocenosis.

The object of the study is the phytogeocenosis of the Kurgan regional arboretum located on a forest plot formed from several parts with a total area of 11.6 hectares of constituent sectors. The territory was provided with the aim to continue research activities on hardy-shrub species cultivation.

Academician V.N. Sukachev deeply defined phytocenosis as any aggregate of plants growing simultaneously on a homogeneous territory and characterized by a certain composition, structure, constitution and interrelations of plants both with each other and with environmental conditions [30]. As the author believed, the nature of these relationships is determined, on the one hand, by the ecological properties of the plants, on the other hand, by the habitat properties being climate, soil and influence of humans and animals.

The ground cover of this area can be divided into following layers: the tree layer, the shrub layer, the grass-shrub layer and the moss-lichen layer.

The factors influencing the formation of phytocenosis are very diverse and differ in individual climatic zones depending on the geographical location of phytocenosis. The main ones are as follows: the ability of plants to settle and reproduce; historical and geological features of an area or site location; features of environmental factors; plants species composition.

Environmental factors (climate, soil, biotic factor and other ones) and vegetation interact, and vegetation impacts the environment when phytocenosis is formed. This creates a certain habitat, which has the criteria necessary for this group of plants existence (Figure 1). 


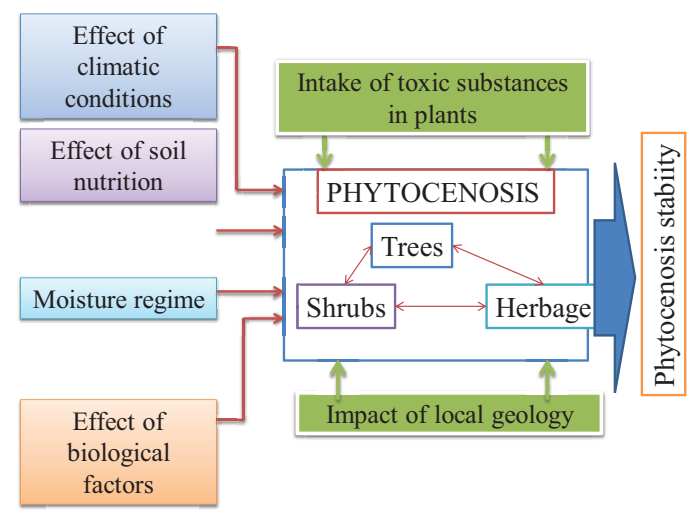

Figure 1: Theoretical model of phytocenosis stability formation mechanisms.

According to M.S. Gilyarov, the more favorable the combination of the above factors of the habitat conditions is, the more diverse the species composition and productivity of the components of the biogeocenosis are. The stronger the growing conditions for most species deviate from the optimum ones, the poorer and less productive the community is, but, concurrently, the more characteristic the biological species that form it and the larger the family of organisms of these species are [31].

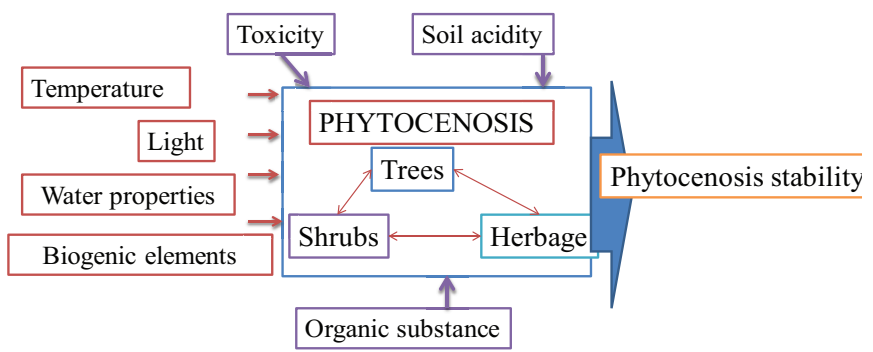

Figure 2: Theoretical model of external environmental influence on phytocenosis stability

The most stringent limiting factor is water. A plant-hygrophyte fades if the air is not saturated with water vapor and the xerophyte tolerates drought well. Another not uniquely influencing factor is environmental temperature. During the breeding season and the beginning of development, all plants are very sensitive to low temperatures but adult specimens can easily tolerate them. Light belongs to the main abiotic factors affecting the vital activity of plants. Photosynthesis can be carried out only in the light, therefore, photosynthetic plants can exist (Figure 2).

Among the complex of factors regulating the stability of phytocenosis, soil conditions, which are referred to as background factors, should be emphasized. The most prominent of them are soil organic matter, soil toxicity and soil acidity. 


\section{Methods and Materials}

\subsection{Methods for assessing the state of phytocenosis}

The most complete characteristic of phytocenosis can be obtained by describing its entire contour. Trial plots of $400 \mathrm{~m}^{2}$ in size $(20 \times 20 \mathrm{~m})$ were laid to describe individual communities, and $100 \mathrm{~m}^{2}(10 \times 10 \mathrm{~m})$ ones to describe herbaceous vegetation [32]. The total projective cover of all layers was estimated, the projective cover was evaluated by layers, and the projective cover of each layer type was assessed. We have applied the definition of species wealth (the number of species in a given society) using Menkhinik index to assess species diversity [33]. This information is required to identify similarities and differences between communities in order to assess changes in species diversity. A simpler and more frequently encountered indicator of floristic similarity is the Jacquard coefficient [33].

\subsection{The method of studying soil water properties}

In our study, we took into account the water properties of the soil including its hygroscopic moisture adsorbed by dry soil from the moisture vapor of the atmospheric air in contact with it. The content of hygroscopic water in the soil depends on the mechanical composition of the soil as well as the relative humidity of the air [34].

Full moisture capacity (the greatest) or soil water capacity is naturally observed in the aquifer.

\subsection{Reaction of soil solution}

On the one hand, soil acidity is created by hydrogen ions in the soil solution and, on the other hand, by absorbed ions. Hydrogen ions precondition active acidity and absorption causes potential (exchange) acidity determined by the potentiometric method.

Quantitative determination of humus in soil is carried out by a titration method based on I.V. Tyurin method [35]. The amount of humus in the soil is a characteristic value for each type of soil. Humus plays an important role in soil fertility while physical and physico-chemical properties of soils depend on the amount and quality of humus. And humus being a source of nutrients stimulates the growth and development of plants.

The method of A.T. Kirsanov [35] determines the mobile compounds of phosphorus in podzolic, sod-podzolic, podzolic-marsh, gray forest, brown forest soils. The method 
is also suitable for non-carbonate black soil. The Truog method has worked well on non-carbonate black soils. The method of B.P. Machigin is a standard method for the determination of mobile phosphorus in carbonate soils (chernozem, chestnut, brown soils and sierozem).

Soil toxicity was determined with the use of ammonium hydroxide by precipitation [35]. Ammonium hydroxide $\left(\mathrm{NH}_{4} \mathrm{OH}\right)$ added in a small amount to a solution containing a copper cation (II) precipitates a basic greenish salt easily soluble in reagent excess. Herewith, the ammonium complex of copper of an intense blue color is formed.

\section{Results}

In the course of the study, the main phytocenoses were examined and soil samples from the sites of the Kurgan regional arboretum were taken for laboratory analysis.

Siberian pine (Pínus sibírica Du Tour), Pine (Pínus sylvéstris L.), Krylov birch (Betula krylovii G. Kryl) are present in all plots of tree species. As for the herbs, there are such kinds as the sedge (Carex praecox Schreb) and the Bluegrass Meadow (Poa praténsis L) found. All other plants are found only in some areas. Phytocenoses of the forest margins Pink and Vitamin-medical are unique in their composition. Thus, 34 species grow on the vitamin-medicinal forest margin, named so due to the predominance of vitamin and medical plants in this territory. This is the richest site with regards to species composition (Figure 2). Starry cereal (Stellāria gramīnea L), meadow-rue (Thalictrum L), Yarrow (Achilléa millefólium L), green strawberry (Fragária víridis Duch), Red clover (Trifolium pretense L.), meadow Cornflower (Centauréa jacéa L), Moss Sphagnum (Sphágnum) and Kukushkin Lyon (Polýtrichum commune Hedw) are abundant there.

Forest margin Pink has 15 species and 7 of them belong to the Pink family. The phytocenosis is unique due to the fact that these plants do not grow in other areas (Figure 3).

The phytocenoses of the sites 3 and 5 are the most similar to each other in species composition.

In general, plant species characteristic for this particular area grow on each site even under the same environmental conditions and anthropogenic impact.

Substantiation of the problem and observations under natural conditions enabled to conclude that the plants of the phytocenoses belonging to the studied territories with respect to soil conditions should manifest the following requirements:

1. undemanding to the nitrogen content since most of them have nodule bacteria; 
2. undemanding to the content of phosphorus and potassium; they all belong to the group of oligotrophic plants;

3. are all within the considered $\mathrm{pH}$ value with respect to soil acidity;

4. are quite sensitive and for some trace elements are indicator plants with respect to trace elements.

The results of the study were processed and subjected to correlation analysis which revealed that most of the detected links are rather weak. This confirms some aspects of the theoretical justification. They can be neglected.

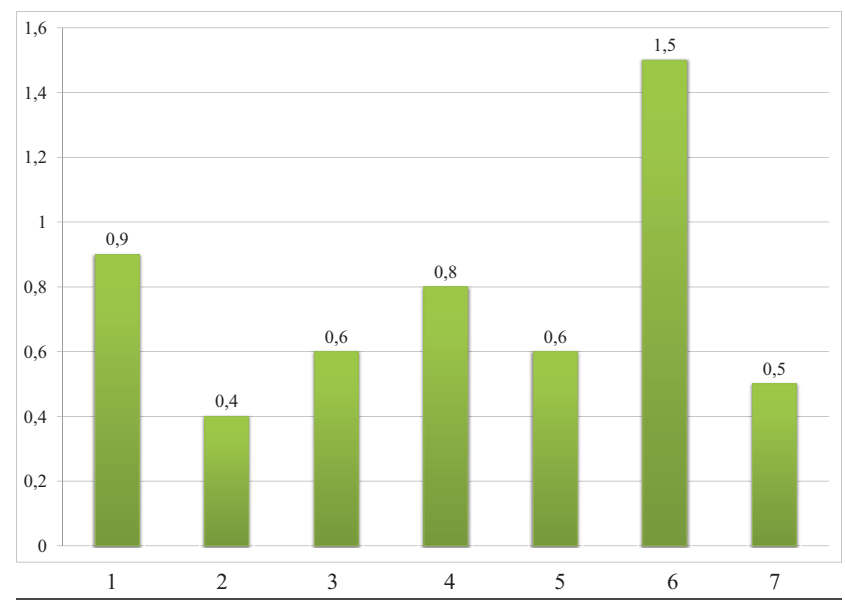

Figure 3: Menkhinik index of species richness.

Note: 1 is plot No. 1, 2 is plot No. 2, 3 is plot No. 3, 4 is the forest margin Pink, 5 is plot No. 5, 6 is the forest margin Vitamin-medical, 7 is plot No.8

However, there was a strong effect caused by accumulation of heavy metals in the soil, primarily iron and copper, they are toxic for many plant species represented in the forested territory of the arboretum and in some cases can cause a change in phytocenosis along with other factors.

The effect of sulfur compounds is not unambiguous; more often, it is an object of plants root nutrition.

On the one hand, hydro carbonate zinc salts have the opposite effect on the plants abundance while an excess of zinc is toxic to plants, but surplus of zinc in the soil is a rare phenomenon. Secondly, plants do not need much of hydrocarbonate-ion since they absorb carbon dioxide from the air for air feeding.

We have found that the following factors influence the abundance and species range of the studied plant communities: 
1. the limiting factors in relation to the abundance of vegetation are the water properties of the soil: maximum hygroscopicity, wilting moisture, field moisture capacity. All these factors characterize water availability for plants in soils with different indicators of water properties. Mechanical composition and soil structure combine these features. All of them are poorly supplied with water, as they are light (sandy and sandy loam) with regards to mechanical composition and are poorly structured;

2. the content of iron in the soil can have a negative impact on vegetation abundance due to chlorosis which develops with its accumulation in the soil and leads to phytocenosis populations death. However, according to generally accepted standards (approximate permissible concentration) and to the results of our research, it was revealed that the iron content in the soil does not exceed the standards.

Copper content in the soil also does not uniquely affect the plants. It can manifest itself both as a toxic element and as a necessary one for the vital activity of certain plant species. Several sensitive species performing the role of bioindicators in relation to the content of copper in the soil, for example, plants from the Pink family (smolevka, etc.) grow on the territory of the arboretum.

Sulphate content may also be a limiting factor. Sulfur is one of the most important elements of plant mineral nutrition. Plants absorb sulfur from soil in the form of ions $\mathrm{SO}_{4}{ }^{2-}$ using root system.

In relation to species richness, water properties of the soil, primarily the content of hygroscopic moisture in it, can also be referred to as limiting factors affecting its stability. This is due to the fact that the maximum content of hygroscopic moisture in the soil is the limit that can primarily lead to plants death demanding soil moisture. However, drought-resistant species that have adapted to these conditions may remain alive. The total field moisture capacity and the range of active moisture are indicators of moisture content, which can also be significant factors for drought-tolerant and waterundemanding species.

In general, the soils of the Vitamin-medicinal forest margin are the most water provided and the most accessible moisture is contained in the soils of the plots numbered 1.3 and the Pink forest margin.

Content of humus in soil also relates to the factors limiting with respect to the species richness of phytocenosis. Content of fulvic and humic acids primarily matters. The predominance of fulvic acids available for plants is a special feature of the light gray forest soils of the Kurgan regional arboretum. Fulvic acids destroy soil minerals and 
promote the transfer of decomposition products to the lower soil layers due to the high acidity of the soil solution. With regards to the presence of humus, all the soils of the Kurgan arboretum are low humus.

In general, the conducted study allowed clarifying the theoretical model of the mechanisms for regulating stability of the Kurgan regional arboretum phytocenoses.

The effect of climatic conditions is determined as one of the mechanisms that regulate phytocenosis stability. Climatic conditions belong to an external environmental factor and manifest themselves in temperature dynamics and light environment conditions (Figure 4).

Support of a moisture regime being a mechanism of phytocenosis stability is governed by the dynamics of water content in soil, which in turn depends on precipitation and moisture content in the subsoil horizon.

The biotic factors mechanism has an internal environmental effect and is manifested through phytocenosis components interaction.

Soil acidity, its toxicity and organic content are distinguished as background factors since they have an indirect effect on the mechanisms. For example, soil acidity affects nutrients mobility, and, hence, the mode of soil nutrition. Organic content performs the function of creating a potential stock of nutrients. As for soil toxicity, it will have an impact on biotic factors.

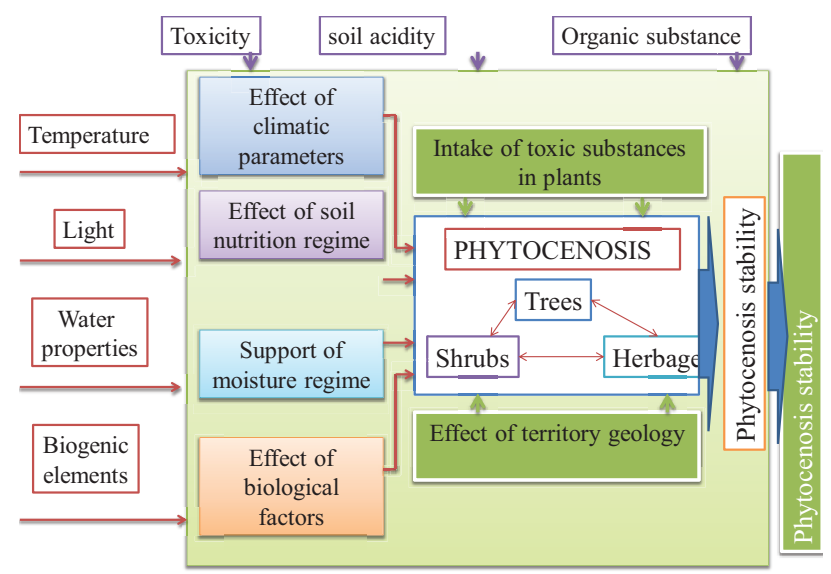

Figure 4: Model of the external environmental factors impact on the mechanisms of phytocenosis stability.

\section{Conclusion}

The conducted research has led to the following conclusions.

1. The models of different factors influencing the resistance mechanisms of the phytocenosis of the Kurgan regional arboretum and built as a result of processing 
materials differ from the theoretical model with regards to the proven differences found in the ratio of limiting and background factors reflecting their regional nature.

2. It turned out during the research that phytocenosis abundance and species richness reacts differently to the one and the same factor.

3. The assumption that all water properties and biogenic elements of a soil affect phytocenosis stability has not been confirmed.

4. The carried out experimental work has shown that the soils under consideration are low fertile, contain a small amount of humus and biogenic elements. However, they are not toxic to growing plants.

5. The phytocenosis stability is influenced by such formation mechanisms as ensuring a water regime; effect of soil nutrition in terms of micronutrient availability; climatic conditions.

All these mechanisms can be indirectly interconnected through the soil acidity and precipitation.

Light soils will allow water to pass through, and chemical elements will actively migrate into soil, which can be a significant factor in the phytocenoses species diversity in different areas of the same area even in the flat topography of soil under the conditions of abundant moistening and as a result of snow melting and precipitation.

6. Methodical recommendations for solving the problem of phytocenosis stability in the Kurgan regional arboretum have been developed. Their main concept is the need for careful selection of plants to increase the species composition diversity phytocenosis and increase its stability in accordance with the soil cover as it is difficult to change the natural soil cover.

\section{References}

[1] Hagvar, S. (1998). The relevance of the Rio-convention on biodiversity to conserving the biodiversity of soils. Applied Soil Ecology, vol. 9(1--3), pp. 1--7.

[2] Laihonen, P., Ronka, M., Tolvanen, H., Kalliola, R. (2003). Geospatially structured biodiversity information as a component of a regional biodiversity clearing house. Biodiversity and Conservation, vol. 12(1), pp. 103--120.

[3] Hillebrand, H., Matthiessen, B. (2009). Biodiversity in a complex world: consolidation and progress in functional biodiversity research. Ecology Letters, vol. 12(12), pp. 1405-1419 . 
[4] Kurkin, K.A. (1998). Interaction of plants in meadow phytocenoses: peculiarities, types, and mechanisms. Russian Journal of Ecology, vol. 29(6), pp. 375--379.

[5] Prieur-Richard, A.H., Lavorel, S., Linhart, Ya., Dos Santos, A. (2002). Plant diversity, herbivory and resistance of a plant community to invasion in mediterranean annual communities. Oecologia, vol. 130(1), pp. 96--104.

[6] Ruijven, Ja., De Deyn, G.B., Berendse, F. (2003). Diversity reduces invasibility in experimental plant communities: the role of plant species. Ecology Letters, vol. 6(10), pp. 910--918.

[7] Landsberg, J., Crowley, G. (2004). Monitoring rangeland biodiversity: plants as indicators. Austral Ecology, vol. 29(1), pp. 59--77.

[8] Bever, J.D., Platt, T.G., Morton, E.R. (2012). Microbial population and community dynamics on plant roots and their feedbacks on plant communities. Annual Review of Microbiology, vol. 66, pp. 265--283.

[9] Hu, S., Li, Y., Wang, W., Jiao, J., Kou, M., Yin, Q., Xu, H. (2017). The antioxidationrelated functional structure of plant communities: understanding antioxidation at the plant community level. Ecological Indicators, vol. 78, pp. 98--107.

[10] Mukhopadhyay, S., Rana, V., Maiti, S.K., Kumar, A. (2017). Biodiversity variability and metal accumulation strategies in plants spontaneously inhibiting fly ash lagoon, India. Environmental Science and Pollution Research, vol. 24 (29), pp. 22990--23005.

[11] Kurkin, K.A. (1999). Ecological niches and synusiae in meadow phytocenoses. Russian Journal of Ecology, vol. 30(3), pp. 155--158.

[12] Onipchenko, V.G., Vertelina, O.S., Makarov, M.I. (1998). Spatial heterogeneity of highaltitude phytocenoses and soil properties. Eurasian Soil Science, vol. 31(6), pp. 622$-628$.

[13] Makarevich, P.R. (2009). Annual succession cycle of pelagic phytocenoses in estuary ecosystems of northern seas of Russia. International Journal on Algae, vol. 11 (1), pp. 57--63.

[14] Privalova, K.N., Zhesmer, N.V., Prudent, M.V. (2010). Efficiency of creating long-term self-renewing phytocenoses. Agrarian science, vol. 3, pp. 15--16.

[15] Romanovsky, M.G., Zavidovskaya, T.S. (2011). Flora and Phytocenosis. Bulletin of Moscow State Forest University -- Lesnoy Vestnik, vol. 4, pp. 205--209.

[16] Ipatov, V.S. (2013). Again about the concept of "phytocenosis". Botanical Journal, vol. 98 (4), pp. 481--486.

[17] Danilov, K.P., Kirillov, N.A., Volkov, A.I. (2015). Problems associated with the introduction of new plant species into the native phytocenosis. Bulletin of the Kursk State Agricultural Academy, vol. 6, pp. 51--52. 
[18] Kalmykova, O.G., Velmovsky, P.V., Bakiev, A.G., Gorelov, R.A. (2017). Modern state of the nature monument "Trout stream Sula" (Northern region of the Orenburg region). Bulletin of Orenburg State University, vol. 8(208), pp. 55--58.

[19] T.V. Dymova, "The criteria for the stability of phytocenoses under the influence of anthropogenic influences", Natural Sciences, vol. 2 (27), pp. 20--26, 2009.

[20] Trifonova, T.A., Shirkin, L.A., Mishchenko, N.V. (2012). Model of stationary states of the system of phytocenoses soil (on the example of the Klyazma river basin). Soil science, vol. 8, pp. 889--890.

[21] Sorokina, O.A., Rybakova, A.N. (2012). The soil-ecological approach in assessing the possibility of using deposits in different stages of successions. Bulletin of Krasnoyarsk State Agrarian University, vol. 5(68), pp. 134--140.

[22] Korolkova, E.O., Shkurko, A.V. (2016). Resistance of marsh phytocenoses of the Polistovsky Reserve to recreational effects. Socio-environmental technologies, vol. 4, pp. 50--77.

[23] Karpachevskii. L.O. (1996). Soil cover pattern. Eurasian Soil Science, vol. 29 (6), pp. 651--656.

[24] Mustafin, A.M., Tyuryukov, A.G. (2012). Phytocenotic role of subsected leguminous grasses on degraded meadows of Western Siberia. Bulletin of Novosibirsk State Agrarian University, vol. 2--1 (23), pp. 21--25.

[25] Zubareva, O.N., Skripal'shchikova, L.N., Perevoznikova, V.D. (1999). Dust accumulation by the phytocenoses in the impact zone of limestone quarries. English Journal of Ecology, vol. 30 (5), pp. 388--312,

[26] Kosnazarov, K.A., Rakhmanov, B.A., Eshzhanov, K.Zh., Kosnazarov, K.K., Romanova, L.K., Orazbayev, T.Zh. (2016). Negative influence of anthropogenic factors on the phytocenosis -- Ferula assa-Foetida L. in the conditions of the desert territory of the Republic of Karakalpakstan. Science and Peace, vol. 1 (7), pp. 64--66.

[27] Kritskaya, T.V., Levchuk, L.V. 2016. Factors of influence on the stability of artificial plant communities in the botanical garden of the Odessa National University. I.I. Mechnikov. Wschodnioeuropejskie Czasopismo Naukowe, vol. 12 (1), pp. 22--26.

[28] Tyrchenkova, I.V. (2017). The Impact of Recreational Effects on the Components of the Forest Phytocenosis of Pure 62-Year-Old Pine Crops. Forest Engineering Journal, vol. 7 (1/25), pp. 96--107.

[29] Prilutsky, A.N. (2009). Biogeocenosis as a living system, distributed in time. Herald of the Northeastern Scientific Center of the Far Eastern Branch of the Russian Academy of Sciences, vol. 3, pp. 64--77. 
[30] Gilyarov, M.S. (1980). Biogeocenology and agrocenology. Structural and functional organization of biogeocenoses, pp. 8--22.

[31] Makhanova, G.S., Durnitskaya, M.S., Radaeva, Yu.G. (2010). Methods of indicator studies in geobotany, Proceedings of the Orenburg State Agrarian University, vol. 3(27), pp. 218--219.

[32] Bukhtoyarov, O.I., Nesgovorova, N.P., Saveliev, V.G., Ivantsova, G.V., Bogdanova, E.P. (2015). Methods of environmental monitoring of the quality of living environments and assessing their environmental safety.

[33] Nesgovorova, N.P., Saveliev, V.G., Neumyvakin, N.A., Ivantsova, G.V. (2017). Organization of the research activity of students: theoretical and applied aspect.

[34] Kaseev, K.Sh., Kolesnikov, S.I., Valkov, V.F. (2003). Biological Diagnostics and Indication of Soils. Methodology and Research Methods. 